ORIGINAL ARTICLE

\title{
Frequency of Obesity among Gastroesophageal Reflux Disease Patients
}

KHADIM HUSSAIN SAMEJO ${ }^{1}$, SANJAY KIRSHAN KUMAR ${ }^{2}$, GHULAMULLAH LAIL ${ }^{3}$, AMIR BAKHSH LANGOVE ${ }^{4}$, SALMAN AHSAM ${ }^{5}$, ASHA DEVI ${ }^{6}$, RAJESH MANDHWANI ${ }^{7}$, NASIR HASSAN LUCK ${ }^{8}$

${ }^{1}$ Senior Registrar, Gastroenterology, Asian Institute of medical science Hyderabad

${ }^{2}$ Senior Registrar, Gastroenterology, Bahria University Medical and Dental College Karachi

${ }^{3}$ Assistant Professor, Gastroenterology, Jinnah Medical and Dental College Karachi

${ }^{4}$ Senior Registrar, Gastroenterology, Sindh institute of urology and transplantation Karachi

${ }^{5}$ Postgraduate Resident, Gastroenterology, Sindh Institute of Urology and Transplantation Karachi

${ }^{6}$ Postgraduate Resident, Gastroenterology, Sindh Institute of Urology and Transplantation Karachi

${ }^{7}$ Senior lecturer, Gastroenterology, Sindh Institute of Urology and Transplantation Karachi

${ }^{8}$ Professor, Gastroenterology, Sindh Institute of Urology and Transplantation Karachi

Correspondence to: Khadim Hussain Samejo, Email:drkhsamejo@gmail.com, Cell: 03313672282

\begin{abstract}
Objective: Gastroesophageal reflux disease (GERD) prevalence ranges from $24 \%$ to $35 \%$ in Pakistani population. Studies have demonstrated GERD frequency is directly proportional to increasing weight. Thus, the frequency of obesity among gastro esophageal reflux disease patients was determined.

Methodology: This cross-sectional study was conducted on outpatients with GERD visiting Department of Hepatogastroenterology, Sindh Institute of Urology and Transplantation, Karachi; from December 2017 to June 2018. Clinical and demographic parameters of study population were recorded. Body mass index (BMI) more than 27 was labeled as obese. Patients with history of ischemic heart disease, pregnancy, ascites and/or Patients on NSAIDS, bisphosphonates or steroids were excluded.

Results: One hundred and fifty patients with mean age of $43.3 \pm 11.5$ years were included in study. Eighty-seven patients $(63.3 \%)$ had age more than 40 years. Majority of study population were males 95 (63.3\%). Mean height and weight of study population were $163.09 \pm 9.56 \mathrm{~cm}$ and $72.92 \pm 15.13 \mathrm{~kg}$, respectively. Mean BMI were $27.55 \pm 6.02$ in which 71 (47.3\%) were obese i.e., BMI >27. Majority were Urdu speaking i.e., 57 (38\%) followed by Sindhi 31 (20\%) Diabetes mellitus was documented in $22(14.7 \%)$ and hypertension in $16(10.7 \%)$ patients. Statistically significant association of GERD was seen in obese females ( $p$-value: 0.018 )

Conclusion: Increase frequency of obesity is significantly associated with GERD. More proportion of obese females has GERD.

Keywords: Gastro esophageal reflux disease; Body mass index; Weight; height
\end{abstract}

\section{INTRODUCTION}

Gastroesophageal reflux disease (GERD) is defined as distressing symptoms or complications that result from reflux of stomach contents(1). This disease may have typical or atypical presentation. In typical form, its principal symptoms are retrosternal burning sensation and regurgitation while in atypical form the patient presents mainly with extra-esophageal symptoms like cough, laryngitis, and asthma. Patient of GERD may present for the first time with chest pain(2,3). According to Dent et al., (4) the prevalence of GERD is 10 to $20 \%$ worldwide, but certain studies done in Pakistan showed that its prevalence ranged from $24 \%$ to $35 \%(5,6)$.Shamail Zafaret al. from Pakistan,(7)demonstrated that the prevalence of GERD (heart burn and/or regurgitation) in obesity ranged from $10.2 \%$ to $22.1 \%$. Hotmen Sijabat et al.,(8)demonstrated8.1 $\%$ prevalence of obesity among GERD in Indonesian population. Several meta-analyses demonstrate a link between body mass index (BMI), waist circumference and weight gain with symptoms and complication of $\operatorname{GERD}(9,10)$. Vaishnav B et al.,(11) demonstrated the prevalence, frequency and severity of symptoms of GERD increases with increase in the BMI.BMI is a key index for relating body weight to height. It is calculated by taking weight in kilograms $(\mathrm{kg})$ divided by height in meters square $\left(\mathrm{m}^{2}\right)$ (12). The incidence and prevalence of GERD have increased markedly worldwide over the recent years, fairly in association with rise in obesity $(13,14)$.

So far only a single study has been performed to establish an association between frequency of GERD and obesity in Pakistan(15). Our study aimed to determine the frequency of obesity among GERD patients. While some studies show that increased waist circumference is strongly associated with GERD, others show that this association is not as significant as that with BMI $(16,17)$. Similarly, weight loss has been shown to be significantly associated with improvement in GERD symptoms(18). Thus, this study would be helpful to establish the frequency of obesity among GERD patients in our population. By application of this study, life style modification can be advised to get rid of distressing symptoms of GERD, which in turn will be beneficial to community by decreasing the symptoms and improving the quality of life.

\section{MATERIAL AND METHODS}

This questionnaire-based cross-sectional study was conducted in the gastrointestinal (GI) outpatients' department of Sindh Institute of Urology and Transplantation, Karachi, from Dec. 2017 to June 2018. A total of 150 patients of both genders, between20 and 70 years of age, having symptoms of GERD for more than the last four weeks, were included in the study by nonprobability consecutive sampling. BMI was calculated by 
taking weight in kilograms $(\mathrm{kg})$ divided by height in meters square $\left(\mathrm{m}^{2}\right)$ of all enrollees (12) and obesity was defined as body mass index (BMI) of equals or more than 27. (19) Those excluded from the study were either those whofailed to give consent, GERD patients with alarm symptoms or with history cardiovascular diseases (ischemic heart disease), pregnancy, ascites due to any cause and Patients taking drugs like NSAIDS, bisphosphonates or steroids during last four weeks. Sample size was calculated 145 by using WHO calculator considering prevalence of obesity in GERD to be $8.1 \%$ in a population (8), a confidence level of $95 \%$ and margin of error 4.5\%.Study was approvedby institutional ethical review committee. All participants were interviewed by the researcher in the outpatient department of Hepatogastroenterology unit, SIUT Karachi. Written informed consent was obtained from all patients fulfilling inclusion criteria. A structured proforma was used to collect data.

SPSS (version 20.0) was used to enter data and analysis. Frequencies and percentages were computed for categorical variables like gender, co-morbidities (DM, HTN, Asthma) and presence of obesity (BMI equals to or more than 27). Quantitative values like age, weight, height and BMlwere presented as mean \pm standard deviation. Effect modifiers like age and gender were controlled through stratification. Post-stratification chi square test was applied. A $p$-value of $\leq 0.05$ was considered as statistically significant.

\section{RESULTS}

A total of 150 patients were included in study, with mean age of $43.3 \pm 11.5$ years, majority were males $95(63.3 \%)$. Eighty seven patients $(63.3 \%)$ were older with age more than 40 and $63(36.7 \%)$ with age equals or less than 40 years, Mean height, weight and BMI were $163.09 \pm 9.56$ $\mathrm{cm}, 72.92 \pm 15.13 \mathrm{~kg}$ and27.55 \pm 6.02 respectively. Out of 150 enrollees, 71 (47.3\%) were obese (BMI >27). (Baseline characteristics are shown in table 1). Almost $60 \%$ females were had higher BMI while majority of males were non obese with significant $p$ value 0.018 (Table 2).

Table 1: Baseline characteristics of the study population.

\begin{tabular}{|l|l|}
\hline Total number of patients & $\mathrm{n}=150$ \\
\hline Age, Mean \pm SD (Range) & $43.3 \pm 11.5,(20-70)$ \\
\hline Males, $\mathrm{n}(\%)$ & $95(63.3 \%)$ \\
\hline Females, $\mathrm{n}(\%)$ & $55(36.7 \%)$ \\
\hline Weight in Kg, Mean \pm SD (Range) & $72.92 \pm 15.13(45-117)$ \\
\hline Height in centimeters, Mean \pm SD (Range) & $163 \pm 9.59(139-183)$ \\
\hline $\mathrm{BMI} \mathrm{kg} / \mathrm{m}^{2}$, Mean $\pm \mathrm{SD}$ (Range) & $27.55 \pm 6.02(16.7-44.8)$ \\
\hline $\mathrm{BMl}>27 \mathrm{~kg} / \mathrm{m}^{2}, \mathrm{n}(\%)$ & $71(47.3 \%)$ \\
\hline $\mathrm{BMI} \leq 27 \mathrm{~kg} / \mathrm{m}^{2}, \mathrm{n}(\%)$ & $79(52.7 \%)$ \\
\hline Age $>40$ Years, $\mathrm{n}(\%)$ & $87(58 \%)$ \\
\hline Age $\leq 40$ years, $\mathrm{n}(\%)$ & $63(42 \%)$ \\
\hline Co-mobidities & \\
Diabetes Melitus, $\mathrm{n}(\%)$ & $22(14.7 \%)$ \\
Hypertension, $\mathrm{n}(\%)$ & $16(10.7 \%)$ \\
Asthma, $\mathrm{n}(\%)$ & $13(8.7 \%)$ \\
Other, $\mathrm{n}(\%)$ & $2(1.3 \%)$ \\
\hline Duration of symptoms & \\
Less than 6 months, $\mathrm{n}(\%)$ & $21(14 \%)$ \\
6months to 1 year, $\mathrm{n}(\%)$ & $59(39.3 \%)$ \\
1Year to 5 years, $\mathrm{n}(\%)$ & $48(32 \%)$ \\
More than 5 years, $\mathrm{n}(\%)$ & $22(14.7 \%)$ \\
\hline
\end{tabular}

Ethnically, majority were Urdu speaking 57 (38\%) followed by Sindhi 31 (20\%)as shown in (Figure 1). Most of the participants did not have any co-morbidities, while DM was present in 22 (14.7\%)participants followed by hypertension $16(10.7 \%)$. Patients were divided in 2 age groups, majority of patients $87(58 \%)$ were older with age more than 40 years out of which 46 were obese and rest 63 (42\%) with age 40 years or less out of which 25 were obese with $p$ value of 0.110 (Table 2). Majority of patients 59(39.3\%) had symptoms from 6 months to 1 year out of which 25 were obese with $p$ value 0.691.(Table 2)Considering various ethnicities, different eating habits especially Urdu speaking use more spices data was analyzed in Urdu speaking and non-Urdu, Of total 57 urdu speaking only 25 were obese $P$ value 0.306 .

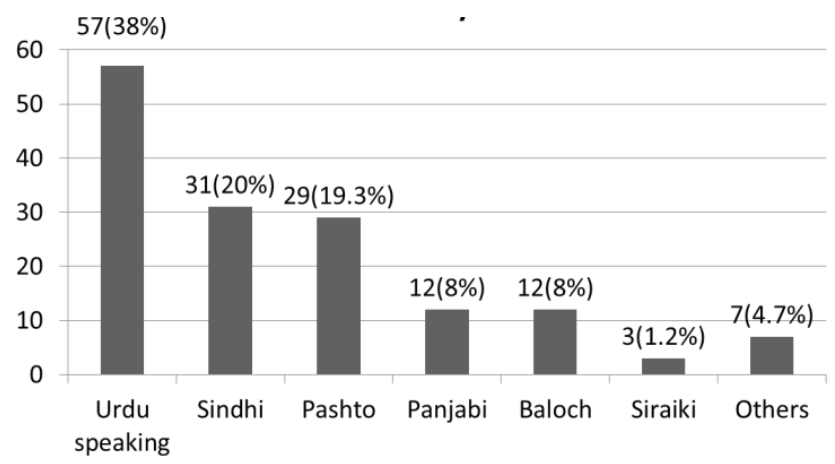

Figure 1: This graph shows the distribution of ethnicity among study population. $(n=150)$

Table 2: This table shows the association between different variables and $\mathrm{BMI}^{*}$

\begin{tabular}{|c|c|c|c|}
\hline \multirow{2}{*}{ Variables } & \multicolumn{2}{|c|}{ Body mass index } & \multirow{2}{*}{$p$ value } \\
\hline & $<27$ & $\geq 27$ & \\
\hline $\begin{array}{c}\text { Gender }(\mathrm{n} ; \%) \\
\text { Male } \\
\text { Female }\end{array}$ & $\begin{array}{l}5 \\
22\end{array}$ & $\begin{array}{l}38 \\
33\end{array}$ & 0.018 \\
\hline $\begin{array}{l}\text { Age Group }(\mathrm{n} ; \%) \\
\leq 40 \\
>40\end{array}$ & $\begin{array}{l}38 \\
41\end{array}$ & $\begin{array}{l}25 \\
46 \\
\end{array}$ & 0.110 \\
\hline $\begin{array}{l}\text { Duration of symptoms }(\mathrm{n} ; \%) \\
<6 \text { months } \\
6 \text { months to } 1 \text { year } \\
1 \text { year to } 5 \text { years } \\
>5 \text { years }\end{array}$ & $\begin{array}{l}9 \\
34 \\
25 \\
11 \\
\end{array}$ & $\begin{array}{l}12 \\
25 \\
23 \\
11 \\
\end{array}$ & 0.691 \\
\hline $\begin{array}{l}\text { Co-morbidity } \\
\text { Present, } n=53 \\
\text { Absent, } n=97 \\
\end{array}$ & $\begin{array}{l}20 \\
59\end{array}$ & $\begin{array}{l}33 \\
38 \\
\end{array}$ & 0.001 \\
\hline $\begin{array}{l}\text { Ethnicity } \\
\text { Urdu speaking } \\
\text { Non Urdu }\end{array}$ & $\begin{array}{l}32 \\
25\end{array}$ & $\begin{array}{l}47 \\
46\end{array}$ & 0.306 \\
\hline
\end{tabular}

\section{DISCUSSION}

According to Jafri Net al.,(4), the prevalence of GERD in Pakistan ranges from $24 \%$ to $35 \%(6)$. Gastroesophageal reflux symptoms (GERS) are very common in Asian population, with a prevalence extending from 50 to $70 \%(20)$. A meta-analysis demonstrated a dose-response correlation between $\mathrm{BMI}$ and the risk of reporting symptoms of GERD between both men and women(21).Shamail Zafar, et al., (7), demonstrated the prevalence of GERD (heart burn and/or regurgitation) in obese individuals ranges from $10.2 \%$ to $22.1 \%$. In this 
studywe reported 150 individuals with GERD of which obesity was found to be $47.3 \%$.Crowell et al., (22) observed more common upper and lower Gl symptoms in overweight females visiting a weight management center compared to normal weight women enrolled from the community. Jacobson et al., (23) conducted a study on a large cohort of female subjects also revealed the positive relation between reported $\mathrm{Gl}$ symptoms and BMI. Furthermore, the author demonstrated that weight gain was linked with an increased risk of symptoms of GERD and weight loss decreases the risk. In our study population 60 $\%$ females had BMI more than 27. We documented statistical significant association of obese females with GERD ( $p$ value 0.018). Obesity is one of potential risk factors in pathophysiology of GERD. An analysis of 1,524 sample established that obesity (BMl> $30 \mathrm{~kg} / \mathrm{m} 2$ ) is a strong risk factor in GERD incidence (24).Pathophysiology of GERD in obesity is considered as multifactorial.The etiology of increased incidence of GERD development in obesity has not been completely understood. It has been described that the lower esophageal sphincter tone is similar or a slightlylow in patients with obesity compared to normal subject $(25,26)$.Several meta-analyses demonstrate a link between body mass index (BMI), waist circumference and weight gain with symptoms and complication of GERD $(9,10)$. Raised intra-abdominal pressure in obesity may cause development of GERD signs and symptoms. Such rise of intra-abdominal pressure may be resulted from deposition of body fat, especially in abdominal region.Accumulated body fat is also affected by certain hormonal factor, which is related with adipose tissue to play role in pathogenesis of GERD. However, the precise mechanism remains unclear(23). There is an increasing intragastric basal pressure in obesity compared to the normal control(27). Vaishnav B et al (11)., demonstrated the prevalence, frequency and severity of GERDsymptoms increases with risingBMI.BMI is a basic index for relating body weight to height. It is calculated by taking weight in kilograms $(\mathrm{kg})$ divided by height in meters square $\left(\mathrm{m}^{2}\right)(18)$. The incidence and prevalence of GERD have increased markedly worldwide over the recent years, fairly in association with rise in obesity $(12,13)$. While HotmenSijabatet al.from Indonesia,(8) demonstrated the prevalence of obesity among GERD is $8.1 \%$.We reported 150 individuals with GERD in which $71(47.3 \%)$ patients were obese. The variation in the results can be attributed to difference in ethnicity and cut off of BMI.Co nsidering various ethnicities, different eating habits especially Urdu speaking use more spices data was analyzed in Urdu speaking and non-Urdu, of total 57 Urdu speaking only 25 were obese $P$ value 0.306 this analysis was performed keeping in view previous data by butt et al that GERD was found in 70 of those who used spicy meals (28).Upper GI endoscopy was not performed due to exclusion of alarm symptoms as per national guidelines. (29) Patients with comobidities like DM, HTN or asthma were associated more raised $\mathrm{BMI}$ having $\mathrm{P}$ value $\boldsymbol{p}=\mathbf{0 . 0 0 1}$.

\section{CONCLUSION}

Increase frequency of obesity $47.3 \%$ observed among gastro esophageal reflux disease patients. Female gender and co morbiditiesi.e DM, HTN were associated more with Obesity and GERD.

\section{REFERENCE}

1. Philip OK, Lauren BG, Marcelo F. Guidelines for the diagnosis and management of gastroesophageal reflux disease. Am J Gastroenterol. 2013;108:308-28.

2. Atkins D, Briss PA, Eccles M, Flottorp S, Guyatt GH, Harbour RT et al. Systems for grading the quality of evidence and the strength of recommendations II: pilot study of a new system. BMC Health Serv Res. 2005 Mar 23;5(1):25.

3. Vakil N, van Zanten SV, Kahrilas P Dent J, Jones R; Global Consensus Group. The Montreal definition and classification of gastroesophageal reflux disease: a global evidence-based consensus. Am J Gastroenterol 2006;101:1900-20.

4. Dent J, El-Serag HB, Wallander MA, Johansson S. Epidemiology of gastro-oesophageal reflux disease: a systematic review. Gut 2005;54:710-7.

5. Karim S, Jafri W, Faryal A, Majid S, Salih M, Jafri F, et al. Regular post dinner walk; can be a useful lifestyle modification for gastroesophageal reflux. J Pak Med Assoc. 2011 Jun;61(6):526-30.

6. Jafri N, Jafri W, Yakoob J, Islam M, Manzoor S, Jalil A, et al. Perception of gastroesophageal reflux disease in urban population in Pakistan. J Coll Physicians Surg Pak. 2005 Sep;15(9):532-4.

7. Zafar S, Haque IU, Tayyab GU, Rehman AU, Rehman AU, Chaudhry NU. Correlation of gastroesophageal reflux disease symptoms with body mass index. Saudi J Gastroenterol. 2008 Apr;14(2):53-7.

8. Sijabat $H$, Simadibrata $M$, Abdullah $M$, Syam AF. Gastroesophageal Reflux Disease in Obese Patients. Indones J Gastroenterol Hepatol Dig Endosc. 2008;9(1):1015.

9. Corley DA, Kubo A. Body mass index and gastroesophageal reflux disease: a systematic review and meta-analysis. Am J Gastroenterol 2006;101:2619-28.

10. Hampel H, Abraham NS, El-Serag HB. Meta-analysis: obesity and the risk for gastroesophageal reflux disease and its complications. Ann Intern Med 2005;143:199-211.

11. Vaishnav B, Bamanikar A, Maske P, Reddy A, Dasgupta S. Gastroesophageal Reflux Disease and its Association with Body Mass Index: Clinical and Endoscopic Study. J Clin Diagn Res. 2017 Apr;11(4):OC01-OC04.

12. Nomura M, Tashiro N, Watanabe T, Hirata A, Abe I, Okabe $\mathrm{T}$, et al. Association of symptoms of gastroesophageal reflux with metabolic syndrome parameters in patients with endocrine disease. ISRN Gastroenterol. 2014 Jan 30;2014:863206.

13. Lee YC, Yen AM, Tai JJ, Chang SH, Lin JT, Chiu HM, et al. The effect of metabolic risk factors on the natural course of gastro-oesophageal reflux disease. Gut 2009;58:174-181.

14. Tseng PH, Lee YC, Chiu HM, Huang SP, Liao WC, Chen $\mathrm{CC}$, et al. Prevalence and clinical characteristics of Barrett's esophagus in a Chinese general population. J Clin Gastroenterol 2008;42:1074-9.

15. Nisar S, Piracha $S$, Masud $F$. The frequency of gastroesophageal reflux disease among obese. Pak J Med Health Sci Oct-Dec 2010;4(4):455-9.

16. Friedenberg FK, Rai J, Vanar V, Bongiorno C, Nelson D.B, Parepally $M$, et al. Prevalence and risk factors for gastroesophageal reflux disease in an impoverished minority population. Obes Res Clin Pract. 2010 Oct;4(4):261-69.

17. El-Serag HB, Ergun GA, Pandolfino J, Fitzgerald S, Tran T, Kramer JR. Obesity increases oesophageal acid exposure. Gut. 2007 Jun;56(6):749-55.

18. Park SK, Lee T, Yang HJ, Park JH, Sohn Cl, Ryu S, et al. Weight loss and waist reduction is associated with 
improvement in gastroesophageal disease reflux symptoms: a longitudinal study of 15295 subjects undergoing health checkups. NeurogastroenterolMotil. 2017 May;29(5).

19. Hsu WC, Araneta MR, Kanaya AM, Chiang JL, Fujimoto W. $\mathrm{BMI}$ cut points to identify at-risk Asian Americans for type 2 diabetes screening. Diabetes care. 2015 Jan 1;38(1):150-8.

20. Goh K. Changing epidemiology of gastroesophageal reflux disease in the Asian-Pacific region: An overview. J Gastroenterol Hepatol. 2004 Sep 1;19(s3).

21. Hampel H, Abraham NS, El-Serag HB. Meta-analysis: Obesity and the risk for GERD and its complications. Ann Intern Med. 2005 Aug 2;143(3):199-211

22. Crowell MD, Cheskin LJ, Musial F. Prevalence of gastrointestinal symptoms in obese and normal weight binge eaters. Am J Gastroenterol. 1994 Mar;89(3):387-91

23. Jacobson BC, Somers SC, Fuchs CS. Body-mass index and symptoms of gastroesophagel reflux in women. $\mathrm{N}$ Engl $\mathrm{J}$ Med. 2006 Jun 1;354(22):2340-8.

24. Locke GR 3rd, Talley NJ, Fett SL, Zinsmeister AR, Melton LJ 3rd.. Risk factors associated with symptoms of gastroesophageal reflux. Am J Med 1999; Jun;106(6):642-9.
25. lovino $\mathrm{P}$, Angrisani L, Tremolaterra F, Nirchio E, Ciannella $\mathrm{M}$, Borrelli $\mathrm{V}$, et al. Abnormal esophageal acid exposure is common in morbidly obese patients and improves after a successful Lap-band system implantation. Surg Endosc2002; Nov 1;16(11):1631-5.

26 O'Brien TF Jr. Lower esophageal sphincter pressure (LESP) and esophageal function in obese humans. J Clin Gastroenterol. 1980 Jun 1;2(2):145-8.

27. Hou $X H$, Xie XP, Xu H, Chen JDZ. Exaggerated gastric accommodation in patients with obesity. Gastroenterology 2004;126;:A481:T13

28. Butt AK, Hashemy I. Risk factors and prescription patterns of gastroesophageal reflux disease: HEAL study in Pakistan. $\mathrm{J}$ Pak Med Assoc. 2014 Jul 1;64(7):751-7

29. Niaz SK, Quraishy MS, Taj MA, Abid S, Alam A, Nawaz $A A$,et al. Guidelines on gastroesophageal reflux disease. $J$ Pak Med Assoc. 2015 May 1;65(5):532-41. 